\title{
The Impact of Human Capital on Stocks Performance in Emerging Markets: Evidence From Egypt
}

\author{
Walid Abouzeid (Corresponding author) \\ Business Administration Department \\ International Academy For Engineering and Media Science - IAEMS \\ 6th of October City, Egypt \\ E-mail:walid_mti@hotmail.com
}

Sharihan Mohamed Aly

Foreign Trade Department, College of International Transport \& Logistics Arab Academy for Science, Technology \& Maritime Transport, Cairo City, Egypt

Received: January 3, 2020

Accepted: January 29, 2020

Published: March 10, 2020

doi:10.5296/ijafr.v10i1.16175

URL: https://doi.org/10.5296/ijafr.v10i1.16175

\begin{abstract}
This study attempts to investigate the impact of human capital on the common stock's return. The population of the study is Egyptian companies listed at the Egyptian exchange (EGX) due to 2014-2018. The statistical results indicate that there is a general tendency to change common stock's hold return to the corporation's human capital, and it is significant at 0.01 levels. In other terms, it can be stated that the corporation's human capital has a significant impact on common stock's hold return in the Egyptian corporation, and according to Adjusted R-squared the corporation's human capital explain a 57.8\% from the change common stock's hold return.so; led to the impact of human capital on creating value of common stock. This can be traced back to investing in "the development and researches" on the other hand besides training, therefore medicine and technology companies get affected through these fields of development researches areas; however companies in industrial and banking sector get impacted by training field.
\end{abstract}

Keywords: Human capital, Intellectual capital, Intangible capital, Stocks performance

JEL Codes: E22, E24, G12, J24, O15 


\section{Introduction}

The business world has witnessed many transitions, mainly due to technological developments, especially after the Second World War, as the world began to witness a war of minds, as there can be no strategic plan except in light of the human elements with efficiency and multiple skills. Therefore; Human capital is the cumulative value of expertise, information, abilities, lives and employee motivation. In other terms; Human capital requires these corporation and contributions that represent the analysis, experience, innovation and decision-making that people contribute to corporation (Kaplan \& Norton, 2004).

Financial markets usually make evaluations for the ability of financial assets, especially from common stock, to generate benefits for shareholders, which can be traced back to the assets they possess that create positive cash flows according to cash dividend discount; Discounted Cash Flow - free cash flow to the firm (FCFF) / free cash flow to equity (FCFE)-; Economic Value Added (EVA) and/or earnings approaches (Francis et. al., 2000; Lamont and Polk 2001; Shrieves et al., 2001; Jiang and Lee 2005; Olweny, 2011; Fernandez, 2007; Garrett and Priestley 2012; Alalawi et. al., 2016; Tijjani and Sani, 2016; Jackowicz et. al., 2017; Pinto et al., 2019 ). Everyone is looking at the source of creating benefits in real assets (profits and cash flows in the financial statements) which creates a return on financial assets (market value moving at uptrend and dividends for shareholders). However; Consider the main source of production and value of corporation is intellectual capital (Nonaka and Takeuchi; 1995) addition to tangible capital.

\section{Literature Review}

It is of considerable importance to determine the factors underlying corporation ' innovativeness and to conduct considerable research. The literature has established positions, such as funding constraints addition to market opportunities (Coad et al., 2016) characteristics of corporation and their market (Hall and Ziedonis, 2001; Freel, 2003; Rogers, 2004;Hewitt-Dundas, 2006; Sung and Carlsson, 2007; Nieto and Santamaría, 2010, Kamal et. al., 2016; Hong et. al., 2016; Fischer et. al., 2018) modes of financing (Best \& Mitra, 1997; Piper, 2000; Lerner, 2000; Brown et al., 2009).

The human capital has long been considered a critical resource to most companies. Literature suggests that the attributes of human capital affects operating outcomes (Huselid, 1995; Wright et. al., 1995; Pennings et al., 1998; Leana and Van Buren, 1998; Hitt at el., 2001; Pepper ,2002; Bosma at el., 2004; Szymanski et al., 2019). It is only logical that human capital is the most important production factor to labor-intensive firms that provide professional services on the basis of domain knowledge.(Nyberg and Wright, 2015; Wu and Chen 2016;Fonti and Maoret, 2016; Mubarik et al., 2018; Bendickson and Chandler, 2019; Harris et al., 2019)

Eventually; corporates must plan for human capital through strategies to stimulate innovation and modernization, whether for products (goods or services), methods of managing operations, and positive interaction with the business environment. According to (Manso;2011) the optimal innovation motivating incentive scheme can be implemented via a 


\section{Ml Macrothink}

International Journal of Accounting and Financial Reporting

ISSN 2162-3082

2020, Vol. 10, No. 1

combination of stock options with long vesting periods, option reprising, golden parachutes, and managerial entrenchment. Therefore; the study found a relation between human capital and corporate value according to the source of creating benefits in real assets (profits and cash flows in the financial statements) which creates a return on financial assets (market value moving at uptrend and dividends for shareholders).

\subsection{Human Capital Definitions}

Human Capital is a measure of the skills, education, capacity and attributes of labor which influence their productive capacity and earning potential.

Human capital, intangible collective resources possessed by individuals and groups within a given population. These resources include all the knowledge, talents, skills, abilities, experience, intelligence, training, judgment, and wisdom possessed individually and collectively, the cumulative total of which represents a form of wealth available to nations and organizations to accomplish their goals.

Human capital is available to generate material wealth for an economy or a private firm. In a public organization, human capital is available as a resource to provide for the public welfare. How human capital is developed and managed may be one of the most important determinants of economic and organizational performance.

Human capital refers to the production factors, coming from human beings; we use to create goods and services. Our knowledge, skills, habits, and social \& personality attributes all form part of the human capital that contributes to the creation of goods and services. Our creativity also contributes. Factors of production are the four inputs required for the production of goods and services. In other words, it is the collection of all our resources. It comprises all our knowledge, abilities, talents, skills, intelligence, training, judgment, and experience. It also includes our wisdom, individually, and collectively. In a national economy, the term refers to how its population contributes towards wealth creation.

Human capital is the economic value of the abilities and qualities of labor that influence productivity. These qualities include higher education, technical or on-the-job training, health, and values such as punctuality. Investment in these qualities improves the abilities of the labor force. The result is greater output for the economy and higher income for the individual.

The investments are called human capital because workers aren't separate from these intangible assets. In a corporation, it is called talent management and is under the human resources department.

\subsection{Factors That Contribute to Human Capital Formation}

A. Education: Education not only raises the standard and quality of living but also encourages modern attitudes of people. Moreover, education increases the productive capacity and productivity of a nation's workforce by honing their skills. Further, education increases the acceptability of the modern techniques and also facilitates a primitive economy to break the shackles of tradition and backwardness. An investment in the education sector has twofold benefits. It does not only increase the income earning capacity but also reduces 


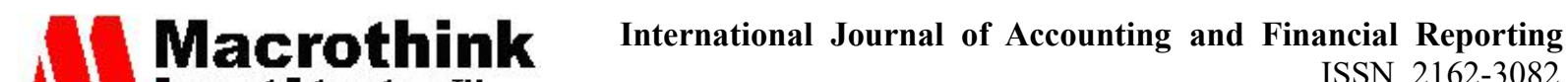 Institute"'

the skewed distribution of income, thereby forming an egalitarian society.

B. Health: The wealth of the country can be increased with the efforts of healthy workforce. Investment in health sector increases, efficiency and productivity of a nation's workforce. In contrast to an unhealthy person, a healthy person can work better with more efficiency and consequently, can contribute relatively more to the GDP of a country. Good health and medical facilities not only increase the life expectancy but also improve quality and standard of living. Investing in health sector ensures the perennial quality and standard of living.

C. On-the-job training: Training refers to the act of acquiring skills, knowledge and competency required to perform a particular job efficiently and effectively. On-the-job training is the most effective kind of framing to a trainee, imparting them with the technical skills and know-how at the actual work site. In this type of training, a trainee is assisted and trained by a trainer when the trainee is actually doing the job. This helps the trainee not only to acquire the: theoretical and practical skills simultaneously but also enables them to learn from the experiences of their trainer and thereby can increase their efficiency and productivity.

At the national level (the country as a whole) there is an international report on human capital issued by the World Bank, but at the company level, there is no similar report; This could be a field of future research.

\subsection{Study Layout}

According to Sun and Ghosal (2020) the human capital indicators play an important role in influencing patenting. In addition, the study expected that human capital affects many other aspects, such as the level of product quality (goods or services) and positive interaction with the business environment. It is a matter that represents an added value for the company and for the shareholders and determines the market value of the shares according to a trend towards risk, and this can be illustrated by the following figure: 


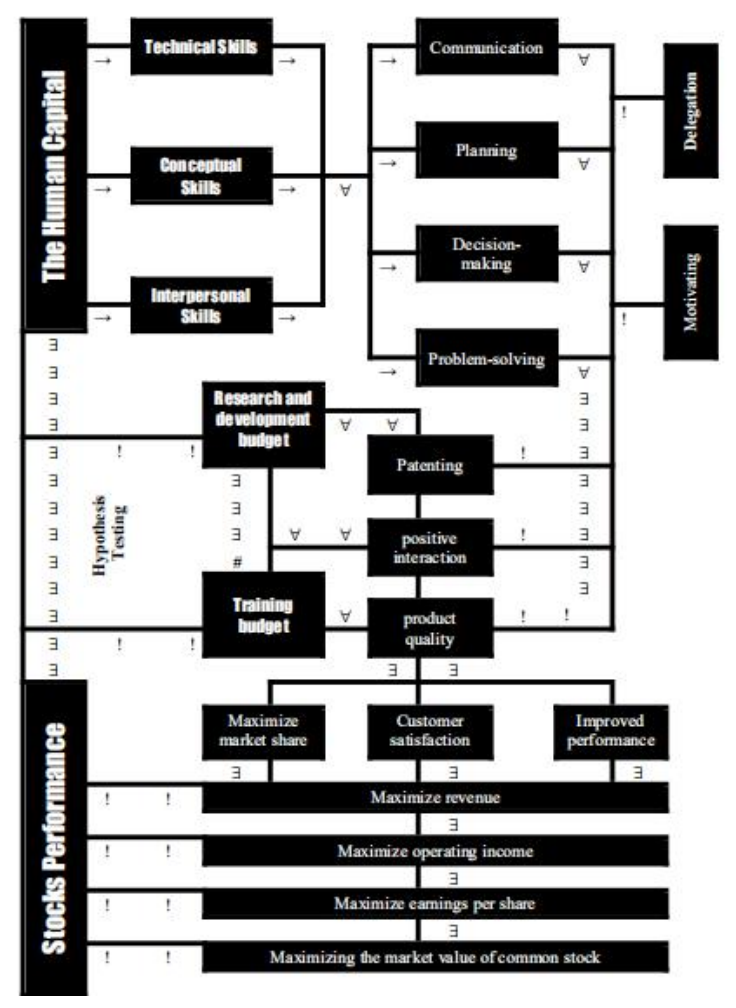

Figure 1. Study layout

According to Katz (2009), the three basic types of management skills include: Technical Skills, Conceptual Skills and Interpersonal Skills; Technical skills involve skills that allow managers to employ a variety of techniques to achieve their goals and their knowledge. The skills include not only operating machinery and technology, manufacturing devices and parts of equipment but also the skills needed to boost sales, develop and sell services and products for various types of products and services. Conceptual skills involve skills includes the knowledge and ability of the skill managers present in the formulation of abstract thinking and ideas. A full definition, an idea and a problem can be evaluated and the director can find creative solutions. This allows the director to foresee challenges efficiently in the department or the whole corporate. The human or the interpersonal skills are the skills that allow managers to communicate, function or connect with employees effectively. These qualifications permit managers to exploit the corporate's human potential and motivate employees to achieve better results.

These are basic skills in administrative activities and impact on their essential missions; There is a wide range of missions that manager should possess to do an effectively and efficiently. The following are four essential missions of managers: Communication, Planning, Decision-making and Problem-solving under two control factors (delegation and motivating).

The efficiency of managers in these essential missions impact on the corporate's performance under two control factors (research and development budget and training budget). The corporate's performance is shown through maximize market share; customer satisfaction and 


\section{Macrothink}

International Journal of Accounting and Financial Reporting

ISSN 2162-3082 2020, Vol. 10, No. 1

improved performance for corporate's operation activities. This is reflected in revenue, operating income, earnings per share (EPS) and the market value of common stock.

According to the above; the study expected that there is an impact of the corporate's human capital on their stocks performance under two control factors. These factors are research and development budget and training budget.

\subsection{Study Problem}

According to study layout; the study is designed to bridge the gap in literature by presenting empirical evidence of the impact of the corporate's human capital on their stock performance; therefore the study addresses the following question:

Is there any impact of the corporation's human capital on the performance of their common stock?

\subsection{Study Hypotheses}

According to study problem; the study hypotheses can be formulated as follows

$\mathrm{H}_{1}$ : There is no significant impact of the corporation's human capital on the performance of their common stock with an immediately.

$\mathrm{H}_{2}$ : There is no significant impact of the corporation's human capital on the performance of their common stock with a lag period.

$\mathrm{H}_{3}$ : There is no significant impact of the corporation's human capital on the performance of their common stock with immediately and a lag period.

\section{Study Methodology}

The study used panel data analysis to examine the impact of the corporation's human capital on the performance of their common stock.

\subsection{Data Collection}

This study is based on secondary data collection. The data for this study was collected from the audited annual financial report published (for determine the investment add at research; development and training according to annual base.); the annual data for the listed companies during 2014 to 2018 (for determine the hold return for common stock according to annual base.). All data were hand collected from the Egyptian Exchange (EGX). The Sample shown in Table 1.

Table 1. The sample

\section{No. COMPANY}

\section{LISTING REUTERS}

DATE CODE

1 Cairo Pharmaceuticals

09/04/1996 CPCI.CA 
2 Commercial International Bank (Egypt)

02/02/1995 COMI.CA

3 Credit Agricole Egypt

03/07/1996 CIEB.CA

\begin{tabular}{llll}
\hline 4 & Egyptian International Pharmaceuticals (EIPICO) & $27 / 09 / 1995$ & PHAR.C \\
\hline 5 & $\begin{array}{l}\text { El-Nile Co. For Pharmaceuticals And Chemical } \\
\text { Industries }\end{array}$ & $27 / 02 / 1995$ & NIPH.CA \\
\hline 6 & Elswedy Electric & $18 / 05 / 2006$ & SWDY.CA \\
\hline 7 & GB Auto & $07 / 03 / 2007$ & AUTO.CA \\
\hline 8 & Qatar National Bank Alahly & $03 / 07 / 1996$ & QNBA.C \\
\hline 9 & Raya Contact Center & $11 / 02 / 2015$ & RACC.C \\
\hline 10 & Raya Holding For Financial Investments & $12 / 05 / 2005$ & RAYA.CA \\
\hline
\end{tabular}

Source: Prepared by the researchers through advice data from The Egyptian Exchange

\subsection{Study Variables}

Data extracted from financial reporting in the study for dependent and independent variables. The following table illustrates different variables that will be used in the analysis.

Table 2. The study variables

\begin{tabular}{|c|c|c|c|c|}
\hline No. & Variables & \multicolumn{2}{|c|}{ mensuration } & Type of Variables \\
\hline 1 & $\begin{array}{l}\text { The investment add at research and } \\
\text { development }\end{array}$ & $\begin{array}{l}\text { Lin } \\
\text { add) }\end{array}$ & (investment & $\begin{array}{l}\text { independent } \\
\text { variable }\end{array}$ \\
\hline 2 & The investment add at training & $\begin{array}{l}\text { Lin } \\
\text { add) }\end{array}$ & (investment & $\begin{array}{l}\text { independent } \\
\text { variable }\end{array}$ \\
\hline 3 & Hold return & $\%$ & & dependent variable \\
\hline
\end{tabular}

\subsection{Study Model}

Application of regression is used to find data-fitting equations. Once the study has the equation of regression, the study can make predictions using the formula. This method is simple and does not take into account the difference between the elements of the study 


\section{MlMacrothink}

International Journal of Accounting and Financial Reporting

ISSN 2162-3082

2020, Vol. 10, No. 1

sample, whether in characteristics such as the size of the company, in addition to the effect of development over time.

Contrarily; Panel data analysis is a factual technique, broadly utilized in sociology, and econometrics to break down two-dimensional (ordinarily cross sectional and longitudinal) board information. The information is generally gathered after some time and over similar unit and afterward a relapse is run over these two measurements. Multidimensional investigation is an econometric technique where information is gathered over multiple measurements;

$$
\mathrm{Y}_{\mathrm{jt}}=\mathrm{A}+\beta_{\mathrm{Fjt}} \mathrm{F}_{\mathrm{jt}}+\mathrm{E}_{\mathrm{jt}}
$$

Where (y) is the dependent variable, (F) is the independent variable, (A) and (B) are coefficients, (i) and (t) are indices for individuals and time; but (e) is The random error ; Through the previous presentation, the study model can be formulated as follows

$$
\mathrm{HR}_{\mathrm{JT}}=\mathrm{A}+\beta_{\mathrm{idjt}} \mathrm{ID}_{\mathrm{jt}}+\beta \mathrm{ID}_{\mathrm{jt}-1} \mathrm{ID}_{\mathrm{jt}-1}+\beta \mathrm{IT}_{\mathrm{jt}} \mathrm{IT} \mathrm{jt}+\beta \mathrm{IT}_{\mathrm{jt}-1} \mathrm{IT}_{\mathrm{jt}-1}+\mathrm{E}_{\mathrm{jt}}
$$

Where:

$\mathrm{HR}_{\mathrm{JT}}$ The hold return for company $(\mathrm{J})$ at $(\mathrm{T})$ time, It's a dependent variable

A Intercept

$\beta_{\mathrm{idjt}} \quad$ Slope of Investment in development with a immediately $(\mathrm{T})$ with the hold return

$\mathrm{ID}_{\mathrm{jt}} \quad$ Investment in development with a immediately $(\mathrm{T})$; It's the independent variable

$ß_{\mathrm{It}-1} \quad$ Slope of Investment in development with a lag period (T-1) with the hold return

${ }_{1} \mathrm{ID}_{\mathrm{jt}-1} \quad$ Investment in development with a lag period (T-1); It's the independent variable.

BIT $_{\mathrm{jt}} \quad$ Slope of Investment in training with a immediately $(\mathrm{T})$ with the hold return

$\mathrm{IT}_{\mathrm{jt}} \quad$ Investment in training with a immediately $(\mathrm{T})$; It's the independent variable

BIT $_{\mathrm{jt}-1} \quad$ Slope of Investment in training with a lag period with the hold return

$\mathrm{IT}_{\mathrm{jt}-1}$ Investment in training with a lag period $(\mathrm{T}-1)$; It's the independent variable

$E_{\mathrm{jt}} \quad$ Random error

downtrend.

Examining the impact of the corporation's human capital on the performance of their common stock with an immediately. 


\section{Mll Macrothink}

International Journal of Accounting and Financial Reporting ISSN 2162-3082 2020, Vol. 10, No. 1

This hypothesis examines the impact of the corporation's human capital on the performance of their common stock with an immediately. The study used panel data cross-sectional units to examine this hypothesis; Table 3 shows the output of $\mathrm{H} 1$.

Table 3. The output of $\mathrm{H} 1$

Model 1: WLS, using 50 observations

Included 10 cross-sectional units

Dependent variable: HR

Weights based on per-unit error variances

\begin{tabular}{llllll}
\hline & Coefficient & Std. Error & t-ratio & $p$-value & \\
\hline const & -111.064 & 18.1478 & -6.120 & $<0.0001$ & $* * *$ \\
\hline LRDT & 10.2750 & 2.52745 & 4.065 & 0.0002 & $* * *$ \\
\hline LTT & 8.46853 & 1.46440 & 5.783 & $<0.0001$ & $* * *$ \\
\hline
\end{tabular}

Statistics based on the weighted data:

\begin{tabular}{llll}
\hline Sum squared resid & 47.56976 & S.E. of regression & 1.006043 \\
\hline R-squared & 0.595690 & Adjusted R-squared & 0.578485 \\
\hline $\mathrm{F}(2,47)$ & 34.62369 & P-value(F) & $5.73 \mathrm{e}-10$ \\
\hline Log-likelihood & -69.70128 & Akaike criterion & 145.4026 \\
\hline Schwarz criterion & 151.1386 & Hannan-Quinn & 147.5869 \\
\hline
\end{tabular}

Statistics based on the original data:

\begin{tabular}{llll}
\hline Mean dependent var & 24.18557 & S.D. dependent var & 10.64541 \\
\hline Sum squared resid & 2962.358 & S.E. of regression & 7.939073 \\
\hline
\end{tabular}

Source: Gnu Regression, Econometrics and Time-series Library output.

The previous statistical analysis indicate that there is a general tendency to change common stock's hold return to the corporation's human capital with immediately, and it is significant at 0.01 levels. In other words, it can be said that the corporation's human capital as with immediately has a significant impact on common stock's hold return in the Egyptian 


\section{Mll Macrothink}

International Journal of Accounting and Financial Reporting ISSN 2162-3082 2020, Vol. 10, No. 1

corporation, and according to Adjusted R-squared the corporation's human capital explain a $57.8 .2 \%$ from the change common stock's hold return.

Examining the impact of the corporation's human capital on the performance of their common stock with a lag period:

This hypothesis examines the impact of the corporation's human capital on the performance of their common stock with a lag period. The study used panel data cross-sectional units to examine this hypothesis; Table 4 shows the output of $\mathrm{H} 2$.

Table 4. The output of $\mathrm{H} 2$

Model 2: WLS, using 50 observations

Included 10 cross-sectional units

Dependent variable: HR

Weights based on per-unit error variances

\begin{tabular}{llllll}
\hline & Coefficient & Std. Error & t-ratio & p-value & \\
\hline const & -88.9491 & 22.4985 & -3.954 & 0.0003 & $* * *$ \\
\hline LRDTL1 & 7.21230 & 2.76633 & 2.607 & 0.0122 & $* *$ \\
\hline LTTL1 & 8.60571 & 1.41758 & 6.071 & $<0.0001$ & $* * *$ \\
\hline
\end{tabular}

Statistics based on the weighted data:

\begin{tabular}{llll}
\hline Sum squared resid & 48.88045 & S.E. of regression & 1.019809 \\
\hline R-squared & 0.475729 & Adjusted R-squared & 0.453419 \\
\hline $\mathrm{F}(2,47)$ & 21.32411 & P-value(F) & $2.57 \mathrm{e}-07$ \\
\hline Log-likelihood & -70.38079 & Akaike criterion & 146.7616 \\
\hline Schwarz criterion & 152.4976 & Hannan-Quinn & 148.9459 \\
\hline
\end{tabular}

Statistics based on the original data:

\begin{tabular}{llll}
\hline Mean dependent var & 24.18557 & S.D. dependent var & 10.64541 \\
\hline Sum squared resid & 3306.501 & S.E. of regression & 8.387555 \\
\hline
\end{tabular}

Source: Gnu Regression, Econometrics and Time-series Library output. 


\section{Mll Macrothink}

International Journal of Accounting and Financial Reporting ISSN 2162-3082 2020, Vol. 10, No. 1

The previous statistical results show that there is a general tendency to change common stock's hold return to the corporation's human capital with a lag period, and it is significant at 0.01 levels. In other words, it can be said that the corporation's human capital as with a lag period has a significant impact on common stock's hold return in the Egyptian corporation, and according to Adjusted R-squared the corporation's human capital explain a $45.3 \%$ from the change common stock's hold return.

Examining the impact of the corporation's human capital on the performance of their common stock with immediately and a lag period:

This hypothesis examines the impact of the corporation's human capital on the performance of their common stock with immediately and a lag period. The study used panel data cross-sectional units to examine this hypothesis. Table 5 indicates the output of $\mathrm{H} 3$.

Table 5. The output of $\mathrm{H} 3$

Model 3: WLS, using 50 observations

Included 10 cross-sectional units

Dependent variable: HR

Weights based on per-unit error variances

\begin{tabular}{llllll}
\hline & Coefficient & Std. Error & t-ratio & p-value & \\
\hline const & -99.1447 & 20.2477 & -4.897 & $<0.0001$ & $* * *$ \\
\hline LRDT & 33.4984 & 7.81896 & 4.284 & $<0.0001$ & $* * *$ \\
\hline LTT & -2.28824 & 3.89212 & -0.5879 & 0.5595 & \\
\hline LRDTL1 & -23.6112 & 7.20620 & -3.277 & 0.0020 & $* * *$ \\
\hline LTTL1 & 9.43895 & 3.47363 & 2.717 & 0.0093 & $* * *$ \\
\hline
\end{tabular}

Statistics based on the weighted data:

\begin{tabular}{llll}
\hline Sum squared resid & 46.62208 & S.E. of regression & 1.017864 \\
\hline R-squared & 0.597735 & Adjusted R-squared & 0.561978 \\
\hline F $(4,45)$ & 16.71663 & P-value(F) & $1.83 \mathrm{e}-08$ \\
\hline Log-likelihood & -69.19821 & Akaike criterion & 148.3964 \\
\hline Schwarz criterion & 157.9565 & Hannan-Quinn & 152.0370 \\
\hline
\end{tabular}


Statistics based on the original data:

\begin{tabular}{llll}
\hline Mean dependent var & 24.18557 & S.D. dependent var & 10.64541 \\
\hline Sum squared resid & 2619.444 & S.E. of regression & 7.629539 \\
\hline
\end{tabular}

Source: Gnu Regression, Econometrics and Time-series Library output.

The previous statistical results show that there is a general tendency to change common stock's hold return to the corporation's human capital with immediately and a lag period, and it is significant at 0.01 levels. In other words, it can be said that the corporation's human capital as with immediately and a lag period has a significant impact on common stock's hold return in the Egyptian corporation, and according to Adjusted R-squared the corporation's human capital explain a $56.2 \%$ from the change common stock's hold return.

\section{Conclusion}

Interest in human capital is not new, as many studies have spotted \& highlighted this concept (Goode, 1959; Frank, 1960; Schultz, 1961; ... e.g.); at the national level (the country as a whole) there is an international report on human capital issued by the World Bank. The 70 years ago witnessed world involve an international transfer of resources in the form of human capital that goes completely unrecorded in any official balance-of-payments statistics (Grubel and Scott, 1966). According to Human Capital Index report for 2018; the rank of Singapore is the first; the second and third was South Korea and Japan; and the rank of Egypt is 104.

As for the company level, there is no similar report; this could be an area for further research. But there is general agreement on the impact of this on company's performance; according to Barney (2015) that the resources of a firm are its primary source of competitive advantage and they include physical capital, human capital and organizational capital resources. Those resources make a improve efficiency for operation actives of the company's.

According to the statistical analysis; there is a general tendency to change common stock's hold return to the corporation's human capital with immediately, and it is significant at 0.01 levels. In other words, it can be said that the corporation's human capital as with immediately has a significant impact on common stock's hold return in the Egyptian corporation, and according to Adjusted R-squared the corporation's human capital explain a 57.8.2\% from the change common stock's hold return. But with a lag period explain just a $45.3 \%$ from the change common stock's hold return. Finally the corporation's human capital with immediately and a lag period explain a 56.2\% from the change common stock's hold return.

This is traced back to investing in "the development and researches" on the other hand besides training, therefore medicine and technology companies get affected through these fields of development researches areas, but companies in industrial and banking sector get impacted by training field. 


\section{References}

Alalawi, A., Kukreja, G., \& Gupta, K. (2016). Free Cash Flow as a Determinant of Performance and Stock Price Movement in Multinational Energy Companies. Journal of Business Management and Information Systems, 3(1), 11-29.

Barney, J. (2015). Firm resources and sustained competitive advantage. In International Business Strategy (pp. 297-315).

Bendickson, J. S., \& Chandler, T. D. (2019). Operational performance: The mediator between human capital developmental programs and financial performance. Journal of Business Research, 94, 162-171.

Best, A., \& Mitra, D. (1997). The venture capital industry in Canada. Journal of Small Business Management, 35(2), 105.

Bosma, N., Van Praag, M., Thurik, R., \& De Wit, G. (2004). The value of human and social capital investments for the business performance of startups. Small Business Economics, 23(3), 227-236.

Brown, J. R., Fazzari, S. M., \& Petersen, B. C. (2009). Financing innovation and growth: Cash flow, external equity, and the 1990s R\&D boom. The Journal of Finance, 64(1), 151-185.

Coad, A., Segarra, A., \& Teruel, M. (2016). Innovation and firm growth: Does firm age play a role?. Research Policy, 45(2), 387-400.

Fernandez, P. (2007). Valuing companies by cash flow discounting: ten methods and nine theories. Managerial Finance, 33(11), 853-876.

Fischer, S., Frese, M., Mertins, J. C., \& Hardt-Gawron, J. V. (2018). The Role of Error Management Culture for Firm and Individual Innovativeness. Applied Psychology, 67(3), 428-453.

Francis, J., Olsson, P., \& Oswald, D. R. (2000). Comparing the accuracy and explainability of dividend, free cash flow, and abnormal earnings equity value estimates. Journal of Accounting Research, 38(1), 45-70.

Frank, A. G. (1960). Human capital and economic growth. Economic Development and Cultural Change, 8(2), 170-173.

Freel, M. S. (2003). Sectoral patterns of small firm innovation, networking and proximity. Research Policy, 32(5), 751-770.

Garrett, I., \& Priestley, R. (2012). Dividend growth, cash flow, and discount rate news. Journal of Financial and Quantitative Analysis, 47(5), 1003-1028.

Goode, R. B. (1959). Adding to the stock of physical and human capital. The American Economic Review, 49(2), 147-155.

Grubel, H. B., \& Scott, A. D. (1966). The international flow of human capital. The American 


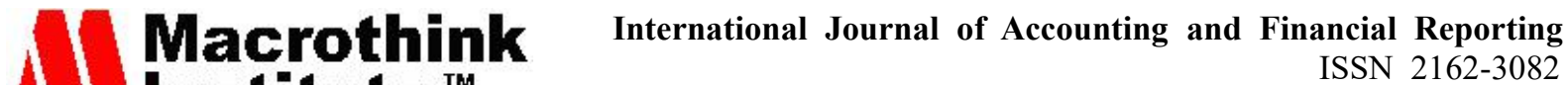 2020, Vol. 10, No. 1}

Economic Review, 56(1/2), 268-274.

Hall, B. H., \& Ziedonis, R. H. (2001). The patent paradox revisited: an empirical study of patenting in the US semiconductor industry, 1979-1995. Rand Journal of Economics, 101-128.

Harris, C. M., Wright, P. M., \& McMahan, G. C. (2019). The emergence of human capital: Roles of social capital and coordination that drive unit performance. Human Resource Management Journal, 29(2), 162-180.

Hewitt-Dundas, N. (2006). Resource and capability constraints to innovation in small and large plants. Small Business Economics, 26(3), 257-277.

Hitt, M. A., Bierman, L., Shimizu, K., \& Kochhar, R. (2001). Direct and moderating effects of human capital on strategy and performance in professional service firms: A resource-based perspective. Academy of Management Journal, 44(1), 13-28.

Hong, S., Oxley, L., McCann, P., \& Le, T. (2016). Why firm size matters: investigating the drivers of innovation and economic performance in New Zealand using the Business Operations Survey. Applied Economics, 48(55), 5379-5395.

Huselid, M. A. (1995). The impact of human resource management practices on turnover, productivity, and corporate financial performance. Academy of Management Journal, 38(3), 635-672.

Jackowicz, K., Mielcarz, P., \& Wnuczak, P. (2017). Fair value, equity cash flow and project finance valuation: ambiguities and a solution. Managerial Finance, 43(8), 914-927.

Jiang, X., \& Lee, B. S. (2005). An empirical test of the accounting-based residual income model and the traditional dividend discount model. The Journal of Business, 78(4), $1465-1504$.

Kamal, E. M., Yusof, N. A., \& Iranmanesh, M. (2016). Innovation creation, innovation adoption, and firm characteristics in the construction industry. Journal of Science \& Technology Policy Management, 7(1), 43-57.

Kaplan, R. S., \& Norton, D. P. (2004). Measuring the strategic readiness of intangible assets. Harvard Business Review, 82(2), 52-63.

Katz, R. L. (2009). Skills of an effective administrator. Harvard Business Review Press.

Lamont, O. A., \& Polk, C. (2001). The diversification discount: Cash flows versus returns. The Journal of Finance, 56(5), 1693-1721.

Leana III, C. R., \& Van Buren, H. J. (1999). Organizational social capital and employment practices. Academy of Management Review, 24(3), 538-555.

Lerner, J. (2000). Assessing the contribution of venture capital. The RAND Journal of Economics, 31(4), 674-692.

Mubarik, M. S., Chandran, V. G. R., \& Devadason, E. S. (2018). Measuring human capital in 
small and medium manufacturing enterprises: What matters?. Social Indicators Research, 137(2), 605-623.

Nieto, M. J., \& Santamaría, L. (2010). Technological collaboration: Bridging the innovation gap between small and large firms. Journal of Small Business Management, 48(1), 44-69.

Nonaka, I., \& Takeuchi, H. (1995). The knowledge-creating company: How Japanese companies create the dynamics of innovation. Oxford university press.

Nyberg, A. J., \& Wright, P. M. (2015). 50 years of human capital research: Assessing what we know, exploring where we go. Academy of Management Perspectives, 29(3), 287-295.

Olweny, T. (2011). The reliability of dividend discount model in valuation of common stock at the Nairobi Stock Exchange. International Journal of Business and Social Science, 2(6), 121-141.

Pennings, J. M., Lee, K., \& Witteloostuijn, A. V. (1998). Human capital, social capital, and firm dissolution. Academy of Management Journal, 41(4), 425-440.

Pepper, A. (2002). Leading professionals: A science, a philosophy and a way of working. Journal of Change Management, 3(4), 349-360.

Pinto, J. E., Robinson, T. R., \& Stowe, J. D. (2019). Equity valuation: A survey of professional practice. Review of Financial Economics, 37(2), 219-233.

Piper, A. (2000). Finance in UK high technology small firms: an overview. Venture Capital: An International Journal of Entrepreneurial Finance, 2(2), 143-153.

Rogers, M. (2004). Networks, firm size and innovation. Small Business Economics, 22(2), 141-153.

Schultz, T. W. (1961). Investment in human capital. The American Economic Review, 51(1), $1-17$.

Shrieves, R. E., \& Wachowicz Jr, J. M. (2001). Free Cash Flow (FCF), Economic Value Added (EVA), and Net Present Value (NPV):. A Reconciliation of Variations of Discounted-Cash-Flow (DCF) Valuation. The Engineering Economist, 46(1), 33-52.

Sun, X., Li, H., \& Ghosal, V. (2020). Firm-level human capital and innovation: evidence from China. China Economic Review, 59. Retrieved from https://07101bcje-1105-y-https-doi-org.mplbci.ekb.eg/10.1016/j.chieco.2019.101388

Sung, T. K., \& Carlsson, B. (2007). Network effects, technological opportunity, and innovation: evidence from the Korean manufacturing firms. Asian Journal of Technology Innovation, 15(1), 91-108.

Szymanski, M., Fitzsimmons, S. R., \& Danis, W. M. (2019). Multicultural managers and competitive advantage: Evidence from elite football teams. International Business Review, 28(2), 305-315.

Tijjani, B., \& Sani, A. U. (2016). An empirical analysis of free cash flow and dividend policy 


\section{Macrothink \\ International Journal of Accounting and Financial Reporting ISSN 2162-3082 2020, Vol. 10, No. 1}

in the Nigerian oil and gas sector. Research Journal of Finance and Accounting, 7(12).

Wright, P. M., Smart, D. L., \& McMahan, G. C. (1995). Matches between human resources and strategy among NCAA basketball teams. Academy of Management Journal, 38(4), 1052-1074.

\section{Appendix}

Appendix A

Stocks Performance

Cairo Pharmaceuticals

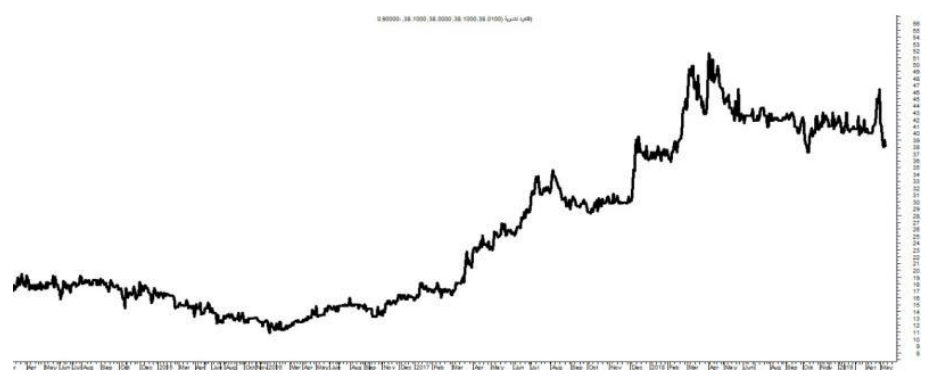

Commercial International Bank (Egypt)

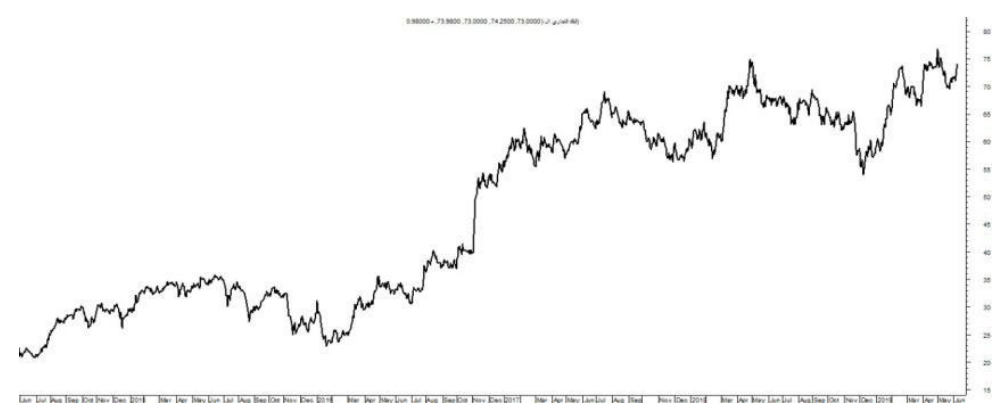

Credit Agricole Egypt

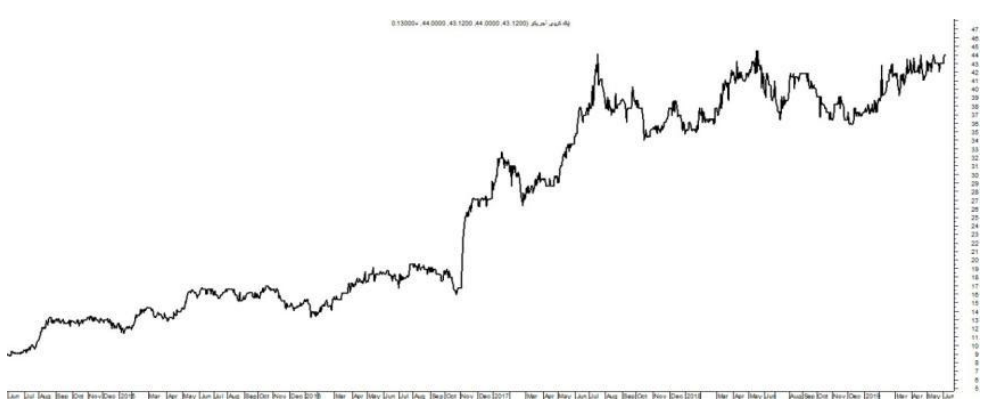

Egyptian International Pharmaceuticals (EIPICO) 


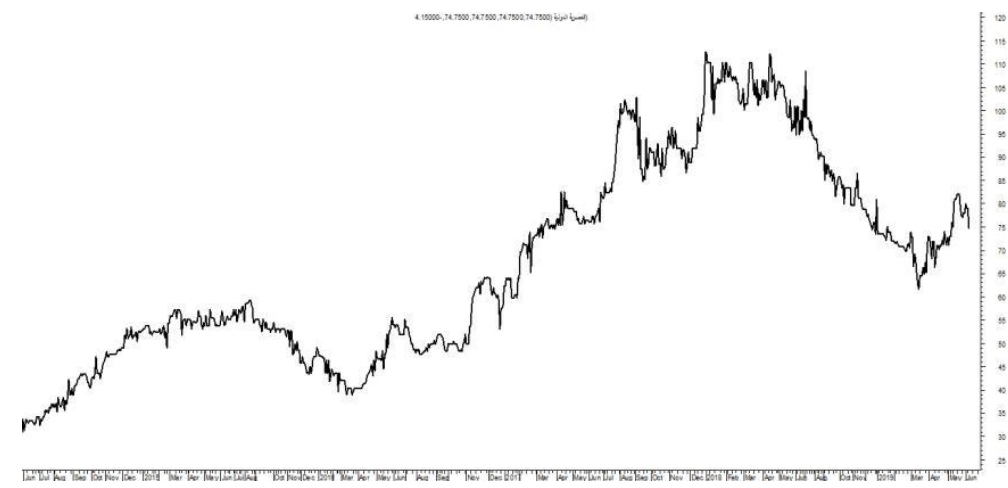

El-Nile Co. For Pharmaceuticals and Chemical Industries

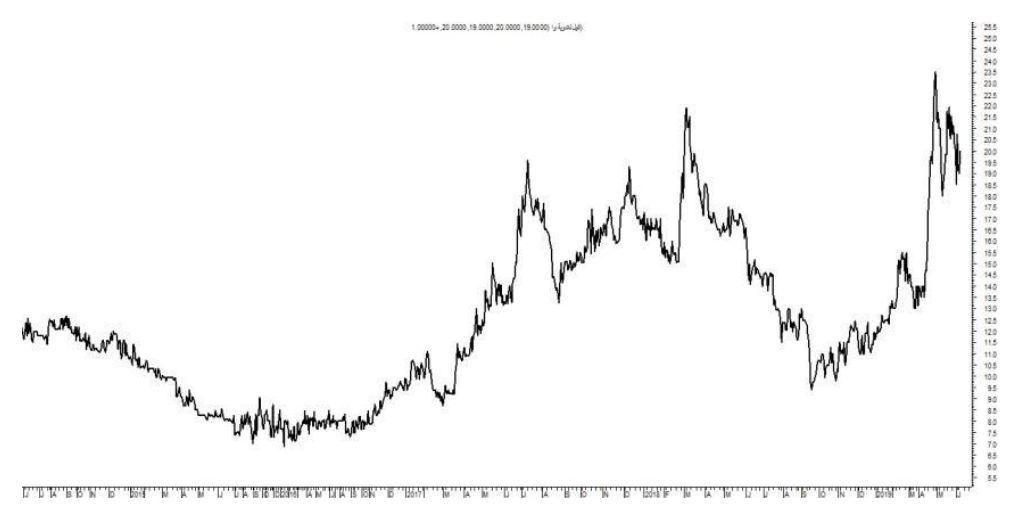

Elswedy Electric

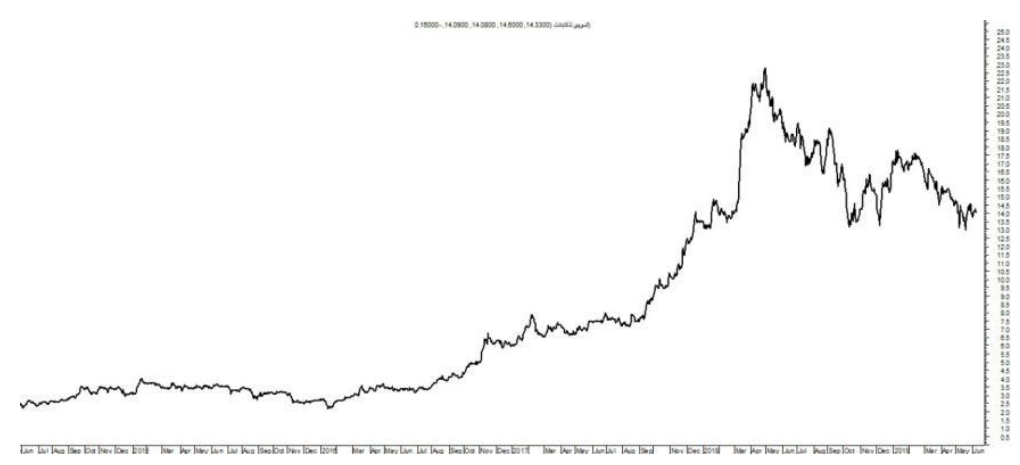

GB Auto

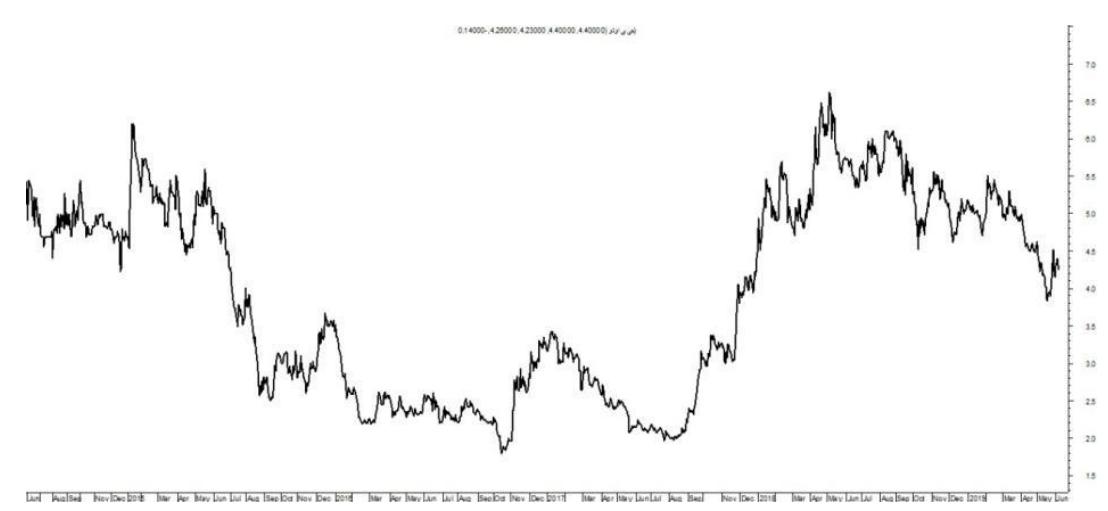

Qatar National Bank Alahly 


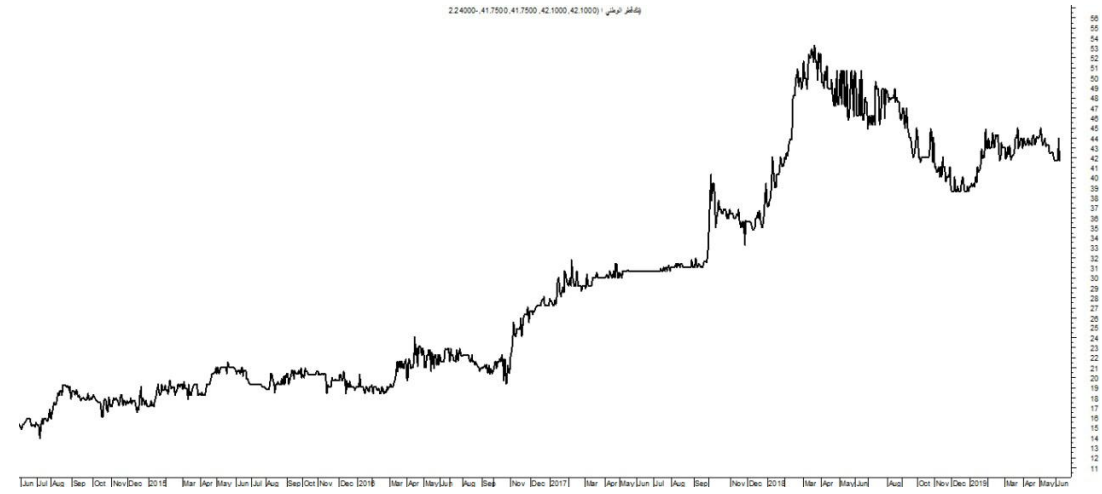

Raya Contact Center

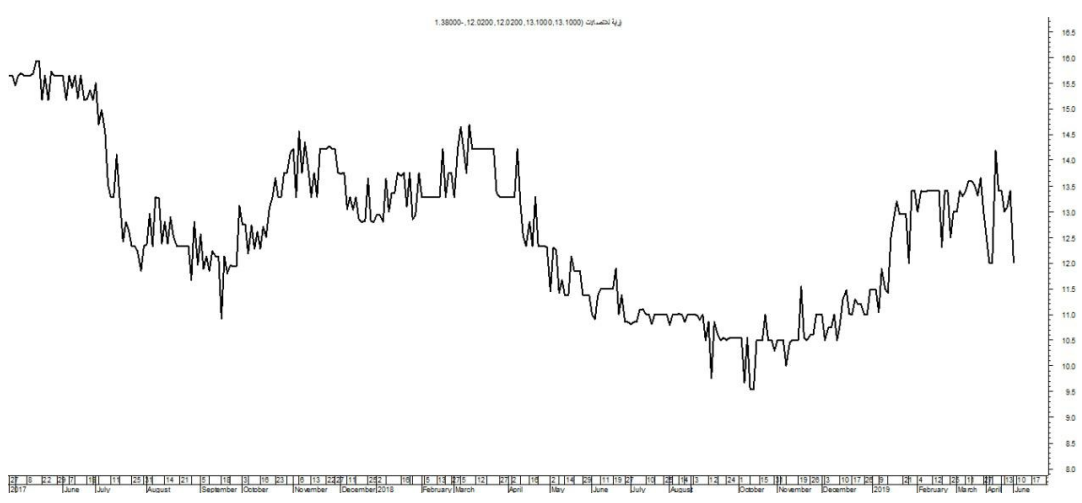

Raya Holding for Financial Investments

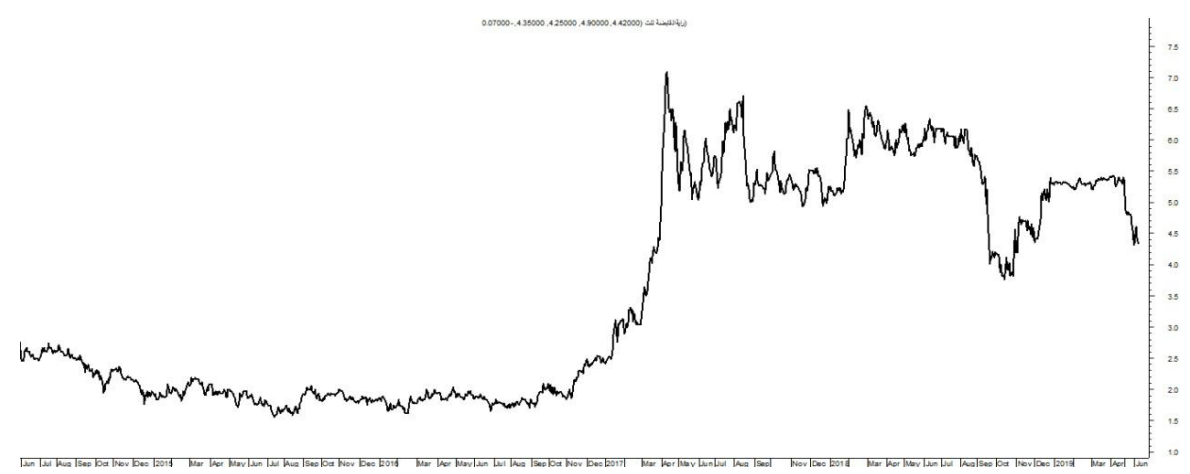




\section{Appendix B}

Statistical analysis output

Descriptives

Descriptive Statistics

\begin{tabular}{|l|r|r|r|r|r|r|r|}
\hline & \multicolumn{1}{|c|}{$\mathrm{N}$} & \multicolumn{1}{c|}{ Mean } & \multicolumn{1}{c|}{ Std. } & \multicolumn{2}{c|}{ Skewness } & \multicolumn{2}{c|}{ Kurtosis } \\
\cline { 2 - 8 } & Statistic & \multicolumn{1}{c|}{ Statistic } & \multicolumn{1}{c|}{ Statistic } & \multicolumn{1}{c|}{ Statistic } & Std. Error & \multicolumn{1}{c|}{ Statistic } & Std. Error \\
\hline HR & 50 & 24.1856 & 10.6454 & 1.225 & .337 & 1.310 & .662 \\
LRDT & 50 & 7.2615 & .3351 & .199 & .337 & -.840 & .662 \\
LRDTL1 & 50 & 7.2402 & .3275 & .205 & .337 & -.921 & .662 \\
LTT & 50 & 7.0972 & .5415 & -.441 & .337 & 1.513 & .662 \\
LTT1 & 50 & 7.0406 & .5755 & -.488 & .337 & .867 & .662 \\
Valid N & 50 & & & & & & \\
(listwise) & 50 & & & & & \\
\hline
\end{tabular}

\section{Correlations}

\begin{tabular}{|c|c|c|c|c|c|c|}
\hline \multicolumn{7}{|c|}{ Correlations } \\
\hline & & $\mathrm{HR}$ & LRDT & LRDTL1 & $\mathrm{LTT}$ & LTTL1 \\
\hline \multirow{5}{*}{$\begin{array}{l}\text { Pearson } \\
\text { Correlation }\end{array}$} & $\mathrm{HR}$ & 1.000 & $.487^{\star *}$ & $.378^{\star \star}$ & $.644^{\star *}$ & $.585^{\star \prime}$ \\
\hline & LRDT & $.487^{\star *}$ & 1.000 & $.938^{* *}$ & $.395^{\star *}$ & .196 \\
\hline & LRDTL1 & $.378^{* *}$ & $.938^{\star \star}$ & 1.000 & $.313^{*}$ & .198 \\
\hline & $\mathrm{LTT}$ & $.644^{\star *}$ & $.395^{\star \star}$ & $.313^{*}$ & 1.000 & $.898^{* *}$ \\
\hline & LTTL1 & $.585^{\star \star *}$ & .196 & .198 & $.898^{* *}$ & 1.000 \\
\hline \multirow{5}{*}{$\begin{array}{l}\text { Sig. } \\
\text { (2-tailed) }\end{array}$} & $\mathrm{HR}$ & & .000 & .007 & .000 & .000 \\
\hline & LRDT & .000 & & .000 & .004 & .172 \\
\hline & LRDTL1 & .007 & .000 & & .027 & .168 \\
\hline & LTT & .000 & .004 & .027 & . & .000 \\
\hline & LTTL1 & .000 & .172 & .168 & .000 & \\
\hline \multirow[t]{5}{*}{$N$} & $\mathrm{HR}$ & 50 & 50 & 50 & 50 & 50 \\
\hline & LRDT & 50 & 50 & 50 & 50 & 50 \\
\hline & LRDTL1 & 50 & 50 & 50 & 50 & 50 \\
\hline & $\mathrm{LTT}$ & 50 & 50 & 50 & 50 & 50 \\
\hline & LTTL1 & 50 & 50 & 50 & 50 & 50 \\
\hline
\end{tabular}

**. Correlation is significant at the 0.01 level (2-tailed)

*. Correlation is significant at the 0.05 level (2-tailed).

\section{Copyright Disclaimer}

Copyright for this article is retained by the author(s), with first publication rights granted to the journal.

This is an open-access article distributed under the terms and conditions of the Creative Commons Attribution license (http://creativecommons.org/licenses/by/4.0/) 